\title{
Nonprofit Church Leaders' Perceptions and Lived Experiences Involving Innovation Competency and Change Management: A Phenomenological Study
}

\author{
Charity R. Addai-Duah, $\mathrm{PhD}$ \\ Walden University, Minneapolis, Minnesota, United States \\ (iD) https://orcid.org/0000-0002-5556-911X
}

Stephanie N. Hoon, PhD

Walden University, Minneapolis, Minnesota, United States

Salvatore J. Sinatra, $\mathrm{PhD}$

Walden University, Minneapolis, Minnesota, United States

Contact: chatrose2003@yahoo.com

\begin{abstract}
Innovation competency among religious leaders has been an area of study as nonprofit researchers continue to discover that conventional ways of managing change are no longer effective when tackling present issues. Discussions regarding using innovation competency to manage change among religious leaders are vague, despite benefits to the nonprofit sector. The purpose of this qualitative phenomenological study was to explore the lived experiences of nonprofit church leaders to better understand how innovation competency has shaped organizational change results. Boyatzis' effective job performance model was the conceptual framework that guided this study. Interview data were gathered from 14 participants who met the inclusion criteria of being a leader with innovation competency experience living in New York, New York. Data from the transcripts were inductively analyzed by using computer software and coded techniques for 10 emergent themes. Results revealed improved organizational performance for church leaders who used innovation competency in managing change, along with spirituality and faith. However, emerging themes showed diverse reasons for innovation competency use and its influences on leaders' behavioral characteristics. Positive social change can be achieved by promoting innovation competency among religious leaders irrespective of spirituality, belief, and doctrine position regarding change management and organizational performance. Outcomes of this study may also provide useful information for religious leaders regarding implementing new ways and programs to help organizational growth.
\end{abstract}

Keywords: innovation competency; church leaders; change management; stakeholders; organizational performance Date Submitted: February 8, 2020 | Date Published: June 3, 2020 


\section{Recommended Citation}

Addai-Duah, C., Hoon, S. N., \& Sinatra, S. J. (2020). Nonprofit church leaders' perceptions and lived experiences involving innovation competency and change management: A phenomenological study. Journal of Social Change, 12, 87-102. https://doi.org/10.5590/JOSC.2020.12.1.07

\section{Introduction}

Christian churches, like many faith-based organizations (FBO), are not immune to change. Church leaders engagement in public and private institutions have been valuable in delivering social services for individuals, communities, and nations (Bielefeld \& Cleveland, 2013; Joakim \& White, 2015; Hong, 2012; Kane \& Jacobs, 2013). Most church leaders approach to managing change for effective organizational performance is limited with innovation abilities due to faith, spirituality and doctrines (Joakim \& White, 2015; Hong, 2012). Without deploying effective innovation, other competencies failed to manage uncertainties or deliver effective organizational performance that benefits followers (Offutt et al., 2016; Probasco, 2016). Globally, nonprofit church leaders face radical changes. Some Christian church leaders may be among those who neglect the innovation competency, which could be the key to confronting change challenges. Innovation competency is an individual's ability to perceive opportunities for change with new thinking and ideas to improve products, processes, or services (Robbins, 2001; Vila et al., 2014). Although there have been many studies on innovation and change management, few have focused on the perspectives and experiences of nonprofit Christian church leaders that use of innovation as a change management competency.

The association between religion and individual development has been burdened with religious conflict and political influence. This association has limited the capability and strength of Christian church leaders to effectively manage changes (Schultz et al., 2016). Probasco's (2016) research on religious organizations, specifically on Christian churches, discovered how faith and doctrines had limited the leaders and their followers' innovation capabilities. Similarly, Schnabel's (2016) noted that nonprofit organization (NPO) leaders limit their audience capacity when only using church values and spiritual frameworks. As much as religion might be good for society, Schnable and Probasco argued that faith and the doctrine of churches could limit innovation use by church leaders. Of use to the NPO sector, researchers recommended further study of religious leaders regarding innovation competency and change management concerning religious leaders' experiences and perceptions.

The prospect of future growth and effective performance for religious leaders using innovation competency in the nonprofit sector, which includes Christian institutions have been established (Assouad \& Parboteeah, 2018; Correa et al., 2017; Singh et al., 2016). However, research about nonprofit leader's perceptions and experiences of using innovation competency and how it shaped organizational change management results in the context of Christian churches are limited. The problem identified in this study is a lack of understanding by some church leaders regarding how innovation competency shaped organizational change outcomes. This problem noted by Mogashoa and Makofane (2017) is that traditionalism and religion limit innovation success. The research question for the study is this: What are the lived experience reflections of nonprofit church leaders regarding how innovation competency shaped organizational change outcomes? The study may help broaden the understanding of innovation competency influence on organizational change management outcomes, from the experiences and perspectives of Christian church leaders. 


\section{Literature Review}

The conceptual framework for this study was rooted in Boyatzis' effective job performance model (EJPM). According to Boyatzis (1982), a "competency is an underlying characteristic of a person which results in effective and superior performance in a job" (p. 21). Further, Boyatzis determined that the highest performance occurred when an individual capability aligns with the tasks and the organizational settings. The EJPM considers how leaders develop expertise from the perspective of the organizational environment, job demands, and individual competencies that include a leader's underlying characteristics. Boyatzis' EJPM supported the study planned in the following: (a) understanding innovation competency components, (b) exploring church leaders' use of innovative competency while managing organizational change, and (c) clarifying the potential impact of having innovation competency on organizational change results.

Nonprofit researchers and practitioners have drawn the attention of innovation competency use in FBOs, particularly Christian leaders, in their managing of organizational change because this is a key to ensure survival in this 21st-century working environment, which involves different needs and desires of stakeholders. Innovation competency is explained as the ability of a leader to manage change or perceive opportunities with new thinking and ideas to improve performance (Janssen, 2003; O’Sullivan \& Dooley, 2009; Vila et al., 2014). The FBOs management are guided by individuals' leadership style and organizational doctrines and beliefs; Clarke and Ware (2015) argued that such practice limits the full usage of innovation competency by leaders regarding the change management process for growth. Improving FBOs' performances and exceeding stakeholder expectations require innovation through creative thinking, dynamic execution, and managed change (Vila et al., 2014). Jorgenson's (2018) study findings showed that leaders are limited regarding creativity and innovation due to their inability to move out from their comfort zones to embrace an unfamiliar leadership approach with new and unrelated abilities within the work-frame. As a result of an unpredictable working environment for FBOs, conventional and fixed ways of leading and managing change are no longer effective when tackling challenges resulted from the change. Religious leaders must deliver innovative answers to ongoing and new difficulties in the FBO environment.

Jassen (2003) found that both profit and NPOs leaders demonstrate workplace innovation competency via behavior, belief, practice, and experience connected to creativity and innovation. Innovation competency is associated with "creative formation, creative promotion, and creative realization" (Hsiao et al., 2017, p. 554). Thus, creativity is the generation of ideas for change; innovation is the application of creative ideas (Jorgenson, 2018). Though creativity and innovation are recognized as critical in most organizations, the necessity of innovation competency is debatably vague for many FBOs (Assouad \& Parboteeah, 2018). To address the identified research gap, which is the limitation of innovation competency by religious leaders, this study would target how FBO religious leaders, particularly Christian leaders' experiences involving innovation competency have influenced organizational change results.

Globally, the leadership of faith-based organizations faces similar challenges regarding innovation competency. The churches in Africa face many challenges because of conflict between traditionalism and the Pentecostalism form of congregating (Mogashoa \& Makofane, 2017). Also, the churches in America have experienced significant changes and face social normative challenges regarding transgender, homosexuality that conflict with the espoused values of the church and other religious institutions (Hmielowski et al., 2015; Spina, 2016). In Asia, many churches are experiencing spiritual transformations because of Pentecostalism and charismatic movement ( $\mathrm{Au}, 2017)$. In Central America, Einer (2013) has shown that religious institutions positioned themselves as advocates for the poor, antiabortion, and moral issues such as sex education and contraception yet face conflicts and opposition from the young generation. Despite the location or the magnitude of the church or FBOs, nonprofit researchers described imperative changes for churches operating 
in a shifting normative environment (Mogashoa \& Makofane, 2017; Spina, 2016). Therefore, to respond to the normative shift and effectively manage the changing environment, churches must transform, and church leaders are responsible for redefining the meaningful outcome.

Change is unavoidable and affects the nonprofit sector. Viederyte's (2016) study deducted that innovation is critical for persistence and strength of NPOs' survival. For religious leaders to engineering organizational performance growth, Hopkins et al.'s (2014) uncovered the need for leaders to possess innovation ability for managing change. Despite the religious leaders' contribution to the social service, stakeholders doubt the leaders' effectiveness, due to limited innovation expertise when managing changes (Joakim \& White, 2015). Aside the numerous roles played by the religious leaders, literature evidence showed the need for them to advance their proficiency with innovations to enable them to manage the continuous changes in the market (Lee \& Trimi, 2016). Churches, like many other FBOs, faced challenges from change. Lee and Trimi's work revealed the need for the religious leaders to build up an intelligible shared attitude on faith and the advancement of innovation. Probasco's (2016) research on religious organizations, specifically on churches, discovered how faith and doctrines had limited the leaders and their followers' innovation capability. The below figure show the overview of the study literature review.

As much as religion might be useful for society, Offutt et al.'s (2016) argued that faith and the doctrine of Christian churches could limit innovation use by the leaders to better the lives of members. Religious leaders play a vital position in terms of social welfare provisions. Christian churches are characterized by beliefs, doctrines, social programs, denominations, and donations; however, the leaders react differently to difficulties involving organizational change. Joakim and White (2015) pointed out that the reaction depends on the individual leader's personalities, principles, organizational policy and structures. As a result of an unpredictable working environment for FBOs, conventional and fixed ways of leading and managing change are no longer effective when tackling challenges resulted from the change. Religious leaders must deliver innovative answers to ongoing and new difficulties in the FBO environment.

\section{Method}

The purpose of this qualitative transcendental phenomenological study was to explore the lived experiences and perspectives of nonprofit church leaders to understand better how innovation competency shaped organizational change outcomes. Moustakas' transcendental phenomenology is centered more on participants' experiences and less on the researcher's interpretations. Also, Moustakas centered on Husserl's idea of epoche, or bracketing, in which researchers put aside their experiences to grasp a fresh viewpoint on the study topic. Thus, an epoche is a "transcendental means in which everything is perceived freshly, as if for the first time" (Moustakas, 1994, p. 34).The population for this study was Christian church leaders from New York City, New York. Griffith (2013) pointed out that selecting appropriate participants for a qualitative study is critical and must be based on the participant's capacity to add to the understanding and meaning of the study topic. This study's population excluded church leaders with less than five years' experience regarding the study topic. Participants were selected based on their willingness to participate in the study. And also meet these eight criteria: (a) the participant was a nonprofit church leader and willing to participate, (b) the leader worked full time in a Christian church organization, (c) the leader have at least 5 years of experience with their current congregation, (d) the leader was an organizational decision-maker, (e) the participant had innovation competency, (f) the participant used innovation to foster organizational change at the church, (g) the participant and the church resided in New York City, (h) the participant signed the informed consent, and (i) the participant had time for interviewed and for any necessary follow-up clarifications. These criteria for participation included the letter of informed consent. 
Purposeful sampling and snowball sampling strategies were used in the selection of 14 participants for this study. The rationale for using these sampling strategies was centered on the assumption that each participant could have provided a unique and vital perspective on a studied phenomenon (Koch et al., 2014).

Semistructured interview served as the primary source of data collection, supported by field notes and reflective journals. The reflective journal was used to bracket the researcher's possible biases as the study design demand. A pilot study was conducted with two eligible participants before actual interviews for the study. These participants were asked open-ended semistructured interview questions on the central research question: What are the lived experience reflections of nonprofit church leaders regarding how innovation competency shaped organizational change outcomes? Data were collected from each participant individually in a separate interview for about $30 \mathrm{~min}$ to $1 \mathrm{hr}$ over 1 month. Member checking was conducted in person and email. The transcribed data collected during the interviews were coded for subthemes and themes using computer software. Following Moustakas' (1994) recommendations, a modified Stevick-Colaizzi-Keen's transcendental phenomenological technique of data analysis was used rather than the Modified Van Kamm strategy. The transcendental phenomenological process employs epoche, phenomenological reduction, imaginative variation, and synthesis in analyzing the data.

\section{Results}

Themes emerged from the collected data that aligned with the research question: The research question was about the lived experience reflections of nonprofit church leaders regarding how innovation competency shaped organizational change outcomes. Also, the theme search activity involved querying the themes to ascertain conformity with the study topic, problem statement, purpose statement, and conceptual framework. Emerged subthemes and themes were supported by the synthesis of the textural-structural descriptions of 14 coresearchers or participants. The subtheme elements contributed to participant meanings of those with scores between 70 and 100. The items higher than 100 are factors participants harped on to convey their lived experiences in innovation competency. The themes became confirmable through the subtheme factors, which the computer software revealed in the word trees (Table 1).

Table 1. Final Themes With Supporting Participants

\begin{tabular}{lc}
\hline \multicolumn{1}{c}{ Theme } & $\begin{array}{c}\text { Total supporting percentages } \\
(\mathbf{N}=\mathbf{1 4})\end{array}$ \\
\hline Fate of organizational culture in change management & $2.41 \%$ \\
Place of spirituality in alternate evangelism & $0.92 \%$ \\
Role of stakeholder influence during transition & $0.87 \%$ \\
Innovation learning curve toward competency & $1.02 \%$ \\
Change management with uncertainties & $0.76 \%$ \\
God's standards when involving modern youth & $0.40 \%$ \\
Role of technology in youth evangelization & $1.00 \%$ \\
Leader-member collaboration in church & $0.56 \%$ \\
Growing innovation competency through experience & $0.43 \%$ \\
People as an interest group factor & $0.70 \%$ \\
\hline
\end{tabular}

\section{Theme 1: Fate of Organizational Culture in Change Management}

Changing the culture of the church organization came in different ways. Though the church leaders came from different educational, professional, technical, social, and cultural backgrounds; maintaining and balancing the 
fate of the organization was critical. The church had a responsibility to stay alive. Remaining on one mandate -that of winning souls-was not producing results for the church.

Therefore, the church must be responsive to the stagnation facing the organization. Lee and Trimi (2016) believed that the focus of innovation is not about value creation for individuals or organizations; instead, it is about building a future that can offer new prospects. This is especially important because of the need to meet the demand of the whole person. Meeting the need would entail addressing both spiritual and natural phenomena in the lives of all who come through the doors of the church.

Participant attitude to the fate of their organizational culture appeared to hang in the balance, as they were mostly irresolute on a decisive action. Einar's (2013) said that religious conventional leadership style of religious leaders, including Christians, were influenced by religion, doctrine, and environment; such an approach limits a leader's performance and social impact. Participants encouraged fellow religious leaders with different beliefs, backgrounds, and cultures to learn and manage change associated with the working environment. In this way, balancing and stabilizing the organization may be achieved. Participant 8 stated, "I encourage fellow religious leaders with different beliefs, backgrounds, and cultures to learn and manage change associated with the working environment." In this way, balancing and stabilizing the organization can be achieved.

\section{Theme 2: Place of Spirituality in Alternate Evangelism}

Spirituality is expected to be part of a church building, and participant stands strong in this area. As immeasurable as spirituality might be, one could ascertain through human interaction, the extent of commitment a person has to a cause is critical. Singh et al.'s (2016) religious institution study revealed how religion and spirituality influenced the success or failure of innovation and depended on the leaders. Alternate evangelism, being different from the older ways of reaching unchurched peoples, arose from the visible enchantment technology has for young people. Participant 6 believed that salvation should remain the main focus of Christian organizations; however, encourage colleagues in the Lord to learn some of the corporate leadership styles and use it to benefit the church.

Viewing the young people as ignorant of the things of God leads to denying the young meaningful involvement roles in God's service. Participant 11 revealed that the spiritual sides of Christian organizations are going well. In other words, the work of God was taking place according to the standard already set from time immemorial. If this revelation is applied to all church organizations, then the wants or needs related to something more than the spiritual might not be actual spiritual but human. The immeasurability of spirituality versus youth love for technology leaves observers guessing the actual milestone the church organizations use this formula to achieve. Therefore, some church leaders pander to the young people interests as a bait to get the young people into the fold and use them to achieve organizational growth. Participant 11 aptly described the young people's situation, "Others saw them unqualified because of their spirituality level and knowledge of our doctrine."

\section{Theme 3: Role of Stakeholder Influence During Transition}

Stakeholders are usually influential, but participants in this research study harped on the depth of stakeholder involvement in decisions affecting church operations. Different church leaders have varied experiences of stakeholder influence. Therefore, the power of stakeholders-as real as it might be-is circumscribable by the worldview of the distinct church leader. Some participants' perception of stakeholders might vary with that of participant born and bred in the space of this research. Also, Participants 5 and 7 evaluated the stakeholders' needs and preferences by comparing them to the traditional system the organization had been using in 
servicing the people. The participants concluded that the needs were different and required disparate assessments before making decisions on the deployment of new paradigms.

Regarding the organizational stakeholders, Participant 9 pointed out that their organizational stakeholders are church members, though literally as an organization, the stakeholders must include government and other interested groups or individuals. In line with the conclusion that stakeholder influence was not the same in all Christians' organizations. Participant 8 revealed that the pressure to use innovation competency was not from the stakeholders directly; rather observed members' behavior and the attitude of the youth toward the activities of the organization. Transition is a phenomenon for the church; both leaders and members have roles to play to achieve the aim of the transition. However, uncertainties becloud the transition effort because of the stakeholder factor.

\section{Theme 4: Innovation Learning Curve Toward Competency}

Individuals face learning curves when they believe in the possible outcomes. The church leaders take steps to learn new ways if they are convinced that the old ways are becoming rather problematic than otherwise. The new understanding of competency in innovation deployment increases the pastor's belief in the learning curve. After encountering the learning curve and observing the competency arising from the learning activity, a pastor would not hesitate to recommend the learning curve. This is especially true and applicable because of the ease with which church operation proceeds. Jaskyte's (2015) study posited that innovation may lead to effective performance for survival and is crucial for faith-based nonprofit leaders. Some of the study participants including Participants 12 and 10 embraced innovation competency to build the church of God and suggested that many people need to join the church; the innovation competency help to accept the change that keeps coming and manages the change for the benefit of the church. The need to embrace the knowledge of technology is better vocalized by an individual who has experienced it. The participants believed that the deployment of innovation would benefit the church and other faith organizations.

\section{Theme 5: Change Management With Uncertainties}

Uncertainties are common in an atmosphere of change. Until the change phenomenon is complete, parties to the phenomenon may remain unsure of the direction to go. This theme conforms to the trend on the phenomenon of innovation competency. Participants in this study considered uncertainties to be particularly critical and inevitable. Church leaders take proactive rather than reactive steps to forestall the ugly outcomes of uncertainties during change. Participant 13 pointed out that feelings, conduct, and attitudes regarding change management in Christian organization has not changed that much; somewhat, has improved and become more flexible and tolerant of the new approach.

Under conditions of uncertainty, the organizational leader would decide which direction to take the organization. Given the uncertainty in business environments, survival rests on a leader's ability to creatively and innovation in managing change that meets stakeholder demands (McMurray et al., 2013). Under conditions of uncertainty, an organizational leader would decide which direction to take the organization. Some of the participants allowed a slight shift from rigidity; hence, the personal attributes have not changed that much. Furthermore, according to some of the participants, they had improved and become more flexible and tolerant of the new approach, which means they chose a slight shift from the status quo instead of stubbornness in the face of unfolding change.

\section{Theme 6: God's Standards When Involving Modern Youth}

Maintaining God's standard regarding managing change with innovation is considered critical. The issue of God's standard when involving modern youth seemed to be of concern to many participants, and the conflicts 
display in regards to change management. Church organizations have followed standards handed down from generation to generation regarding the process and specific religious rites to be performed during church services. The seniors in Christian organizations have their beliefs and style of worshiping God while the youth have developed their method of worshiping God. Participant 12 pointed out that the word change alone has its challenges, and the obstacle of acceptance to the change management relates two opposing; those who agree or disagree. Those beliefs were simply the direct prescriptions in the Bible and the commitment to carry out those prescriptions to the letter. On the contrary, modern youth tended to be exploring modern ways to execute God's instructions. The difficulties inherent in getting young people to commit to God's standards are only psychological.

Using faith and loyalty principles by the church leaders in managing their organizations is useful; however, Singh et al. (2016) said these principles are not enough to deliver lasting solutions to the challenges within FBO settings. Those items constitute God's standards in churching. Kaunda's (2016) listed factors such as "worldview shift, demographic shift in Christianity, socio-political and economic pressure, globalization, and pluralism as contributing factors to FBOs challenges" (p. 114). Adults who believed in the hard copy Bible regarded the new technology adults as members who are falling out of grace. Participant 11, who did something like what Participant 9 did state that the system of worship had changed, and the involvement of the youth group cannot be avoided. These participants understood the change and, and the involvement of the youth group cannot be avoided.

\section{Theme 7: Role of Technology in Youth Evangelization}

The church leaders are expected to be genuinely concerned about the role of technology in evangelism, especially the youth. In the new church environment, leaders and followers began to witness new programs, new attitudes, and unexpected happenings. As long as those surprises favored the organization, technology would serve in youth evangelization. Participants acknowledged the change related to technology, demands, desires, style, approach, structures, and many other things and how all these have influences on their lives. Participant 13 asserted that priority should be given to technology and demands of the members remain the focused of change management in the Christian intuitions. All these have effects on our lives. Technology gradually entered the church, caused a stir, and disrupted the process flow before achieving acceptance.

Though the organization has been surviving the turbulence of both internal and external pressures, the use of innovation competency has turn surviving to maintenance of members and improvement of services.

Participant 7 caution the church communities about conducting services and outreach programs by following laid down principles that were set up by the founders. The older generations of church members are in the best position to determine the effect of a new direction. Any deviation from or alteration to the spiritual emphasis would be visible to the older members who have been with the organization over a long period. The ability to do everything with technology as seamlessly as when technology had not been introduced was worth emulating as expressed by participants. Technological advancement, therefore, becomes the leading choice in modern times. When the youth fall in love with the way the church is going about introducing God to the community, the church experiences growth.

\section{Theme 8: Leader-Member Collaboration in Church}

Collaboration between the leader and members in a church organization would expectedly simulate the relationship between Jesus Christ and His disciples. It must have been with such an understanding that a participant might have witnessed church growth and increase in the community. Lee and Trimi's (2016) work revealed the need for the religious leaders to build up an intelligible shared attitude on faith and the advancement of innovation. Collaboration between the leader and members makes joint project execution 
possible. Participants pointed out that members are part of motivators; through their pressures, something new was implemented with new ability and approach in the organization for a positive outcome. This collaboration is because the leader identifies a need, identifies human resources among members, harnesses the resources, articulates the vision, and deploys human resources.

Religious leaders' position in the social and cultural framework of individuals, communities, and nations are critical to the chosen lifestyle of their followers. Hmielowski et al.'s (2015) study uncovered the vital role that religious leaders' messages play in shaping the (a) lifestyle of individuals, (b) values espoused in their communities, (c) response to environmental issues, and (d) adoption or modification of government policies. Whoever leads the church organization must work with others for the mission and vision of the church to become a reality. Unfettered access to the leader's office is necessary for members of a church organization for effective organizational operation. Participants who testified to innovation competency harped on the role of people among whom were stakeholders and members. Those who testified to obstacles harped on the role of people in fomenting obstacles.

\section{Theme 9: Growing Innovation Competency Through Experience}

Learning is the way out for an organizational leader pursuing the implementation of innovation. Participants believed that learning improves one's capability in achieving a task and the experience had enhanced leadership abilities to complete tasks. The leader's weak area or discipline would require boosting prior to innovation implementation. Sangmi and Jae-Sung (2014) found that innovation usage for organizational sustainability depended on the perspective and ability of the leader. The leader may proceed with implementation when the boost takes place, and the church leaders in this study express their confidence in the understanding they possess of the tasks ahead. Participant 8 and Participant 3 described their visit to similar institutions that had experienced an improvement in organizational performance with innovations. According to these participants, they observed and learned from the leaders that had made it regarding innovation competency.

Some participants extoll the virtues of improvements through innovation without revealing the origin of their experience. When experience gives rise to developments, members of an organization pay more attention to the growth and less to what gave rise to it. The experience is essential when the organization faces the need without a knowledge of the way forward. Sangmi and Jae-Sung's (2014) concluded that leaders with innovational expertise could improve their organizational performance. While innovation competency is an experience, the outcome of that competency could be a whole different experience. When a person is competent in discipline, that person's mannerism reflects that competence. In this regard, members of a church organization can confirm through observation the level of confidence their organizational leader exudes.

\section{Theme 10: People as an Interest Group Factor}

Whether the people are mere members or members with stakeholder status, any emerging change must be managed to make sense to the members. The people are entitled to a friendly atmosphere and environment. The people are the only resources that could collaborate with leaders. As explained by Jaskyte (2015), there is similar pressure on the FBO leaders to meet the fundamental level of quality of service among competing service alternatives for members, donors, and regulators. Therefore, leaders usually build phenomenon around people, some of whom are stakeholders or people who are merely happy to be part of the goings-on. Participant 3 pointed out that change is all about people, so leaders must have the courage to handle "people issues." This requires loving people and expecting opposition. 
The effect of people-speak in or around the church organization could be positive or negative. Participants emphasized on the desires and the demands of present stakeholders and how they are different from what the church used to know and do. Participant 11 viewed supported the changing demands of stakeholders Most of the participants showed concern of the government oversight and the influential powers of the people resulted of fear in the organization and leadership. Whatever the people observe, whether blurred or glaring, the people share with friends and well-wishers. A church organization has received new members in droves because a happy member went out and spread the message of good treatment from the church. Conversely, an unhappy member could go to town with tales of woe that could hinder people from trying out the church. Some participants specifically, showed concern of not all stakeholders, including congregates, would speak well of the leader or the organization; however, leaders must focus on achieving their goals.

\section{Discussion}

The findings from this study are consistent with the growing body of literature on innovation competency and change management in NPOs. The themes of the study align with Langer and LeRoux's (2017) study, which pointed out that the high service demands from stakeholders have caused nonprofit leaders to seek new approaches that work more effectively in responding to changing environmental demands. The attitude of the study participants' concerning the fate of the organizational culture appeared to hang in the balance. The church leaders in this study expressed feelings of suspense involving churches to change the spiritual-only mandate, which is the culture of winning souls; such view did influence the theme God's standards when involving modern youth less percentage of responses from the leaders. Lee and Trimi (2018) pointed out the necessity of innovation due to many societal levels and social challenges such as ethnic conflicts, cultural and political disparities, rising crime rates, worsening conditions of the environments, and global unemployment.

The church leaders experienced uncertainties before, during, or after change management; however, they insisted on being strong to maintain God's principles. Lee and Trimi (2016) believed that the focus of innovation is not about value creation for individuals or organizations. Instead, it is about building a future that can offer new prospects. This is especially important because of the need to meet the demand of the whole person. Christian leaders are expected to engage the young generation with innovative ideas in which things can be done differently. Also, maintain both the youths and Christian organizational values; and match the thought processes and Christian practices of the church continue to be important in religious institution.

Considering that church activities are characteristically spiritual, the individuals serving as pastors have not normally been highly educated individuals regarding innovations. Therefore, innovation competency would probably pose learning challenges, especially for those challenged in cognitive ability. Becoming an innovative leader is a learning process. Achieving transition for the church requires the involvement of both leaders and members. Joakim and White (2013) emphasized the importance of religious leaders, including church leaders about innovation and their handling of changes and pressure from stakeholders. Stakeholders in this research study were individuals occupying diverse portions of the space antecedent to the church organizations and their activities. Sangmi and Jae-Sung (2014) concluded that leaders with innovational expertise and experience could improve their organizational performance. When the church organization is going through changes, stakeholders do not act in the same way at the different church organizations. While a participant would report the cooperation of stakeholders at his organization, another participant would report the total rejection of innovation by their organization's stakeholders. Furthermore, within an organization, a pastor would have the support of one or two stakeholders while the rest of the stakeholders are against innovation.

Evangelism is a crucial activity in the church, which is a spiritual act. However, this research study has found an alternate evangelism paradigm that hinged on technology and youth participation. Kumar Basu (2015) 
determined that change has become a part of the 21st century; leaders should have the mechanism to adjust and manage for growth and survival. The theme place of spirituality in alternate evangelism and the role of technology in youth evangelization are in agreement with the previous literature review. The participants talk much about three things, (a) the pastor of the church, (b) the message the pastor preached from the pulpit, and (c) the service atmosphere, especially if technological gadgets are in service such as overhead screens, musical instruments, highly talented instrumentalists and vocalists as well as melodious tunes. In some of the instances, a pastor insists on deploying technological innovation because there appears to be no other way out of the imminent collapse of the organization. Aside from the significant role religious institutions and their leaders play, other factors continue to be part of social movements in the world.

The findings address the problem identified in the literature review that a need exists to explore the phenomenon of innovation competency use to manage change in faith-based institutions from the views of church leaders for an in-depth understanding of the phenomenon. Faith-based leaders may now be able to appreciate, understand, and used these findings that are peculiarly relevant to leaders and benefit followers, including stakeholders. The importance of such understanding could be made more pertinent when people realize that church leaders and other FBOs leaders' competency play a critical role in change management effectiveness in any organizational performance. Kumar Basu (2015) determined that change has become a part of the 21st century; leaders should have the mechanism to adjust and manage for growth and survival. Leaders need help, donations, and loyalty of stakeholders to be able to manage change successfully with innovation competency. Lee and Trimi (2016) pointed out that faith-based leaders need to corroborate and share intelligence for the advancement of innovation in the FBOs. To increase performance, McMurray et al. (2013) suggested the need for the leaders to have innovative ideas to manage change.

In this study, the youth involvement in change management with innovation competency is critical for effective evangelism and church growth as experienced by study participants. Religious leaders need to develop competencies that might result in productive outcomes and guarantee organizational longevity (Ware et al., 2016). Managing change successfully for effective organizational performance can be enhanced considerably, if faith-based leaders acknowledge, accept, and practice these discovered components such as the fate of organizational culture in change management; place of spirituality in alternate evangelism; role of stakeholder influence during transition; innovation learning curve toward competency; change management with uncertainties; God's standards when involving modern youth; role of technology in youth evangelization; leader-member collaboration in church; growing innovation competency through experience; and people as an interest group factor. The help, donations, and loyalty will remain elusive if leaders ignored the change and fail to meet the expectations of stakeholders. The themes identified in this study need to be appropriately contextualized for relevancy during the application of findings. Different organizations being in nonprofit or for-profit may warrant the need for the modification of some of these components. For instance, the aspect of God's standard and spirituality may be related to the church and its leaders. Also, the evangelism and the approach by the church leaders may be unconventional to the reality of some organizations and their leaders; therefore, individual leaders must act within the context.

\section{Implications for Social Change}

At the individual level of positive change, this study has the potential to improved church leaders' effectiveness and organizational performance. Because church leaders are expected to manage unpredicted change, and understand the environment by monitoring the trend of change in the context of their workplace to benefit congregates (Szczepaska-Woszczyna, 2014). A leader's ability to perceive change with a foreknowledge and creative approach to managing change may be achieved with innovation competency (Assouad \& Parboteeah, 2018). The perception of nonprofit stakeholders regarding the church and the followers' dependency on the public fund is becoming critically debatable in the nonprofit sector where 
religious leaders need to address, and innovation competency may help address this concern. Spirituality remains the main backbone of the Christian church; however, the inclusion of innovation competency may boast evangelism to achieve growth in finances and membership. Additionally, the Christian church leaders' involvement of young people may help expand the leaders' influence on the young generation, and such a move could benefit the community and society regarding crime reduction, high enrollment of education, and church growth.

The study may have positive social change implications at the organizational level. The effective organizational performance of the Christian institutions regarding growth in membership, finances, technological advancement, and development programs may require the innovation competency of the leaders. Learning specific skills by church leaders may better-aligned innovation competency to the needs of the stakeholders. The effective deployment of innovation competency may work better with leadership experiences of Christian church leaders to managed change to influence members, communities, and other stakeholders positively (Ware et al., 2016). Innovation competency may improve the possibilities of Christian institutions' faith practices and performance, leading to the possibilities of stakeholders' satisfaction and retention.

The implications for positive change on the family level are promising. As evidenced by study findings, innovation competency may improve leadership effectiveness of the Christian church leaders and the organizational performance; through the process of information sharing, and unity with stakeholders. Although the collaboration and unity could facilitate the effectiveness of the innovation competency in the context of Christian churches and FBOs, the leader must work in collaboration with stakeholders in a family manner (Spina, 2016). Innovation competency may enhance growth in membership and community programs, and this could be possible under a collaborative atmosphere between the leaders and stakeholders working as a family. Collaboration between the leader and members may work in joint project execution because of innovation competency by leaders. The use of innovation competency could enable the Christian church leaders to identify a need, identifies human resources among members, harnesses the resources, articulates the vision, and deploys the human resources effectively to benefit society.

At the societal level, the Christian church leaders who are spirit-filled individuals and concerned about the social and well-being of others may improve the social welfare programs of FBO with innovation competency. Innovation competency may help youth evangelism in communities and campus ministry with available technology software; this may help transform many youth from the street. Technological advancement, therefore, has become a critical choice in modern times for the Christian church leaders and FBOs; and innovation competency may help to transition the organization to meet the demands of stakeholders. For a church organization to succeed in executing its mandate, people must be the focus of the leaders as individuals and the organization as a corporate body. People are in the center of all church organizational activities; therefore, innovation competency may strengthen the Christian church's leadership in managing the changing needs of the people and enhance their reputation from the public perspective.

\section{Recommendations}

This study was conducted to narrow the innovation competency gap noted within the nonprofit sector, specifically Christian churches from the literature review. A critical limitation of the study was the sample of the church leaders for the interviews. This could limit study evidence, and such restricted the generalizability of the study outcome across the FBOs and to the NPO sector. The different ideologies, educational levels, and the doctrines of the religious leaders may limit the study outcomes. The focus on church leaders is related to the existing literature on Christian leaders. Hence, leaders from other religious institutions did not participate in this study; for this reason, the findings of this research may not be reflective of this population. Thus, 
further investigation could be useful to address the shared experience of these leaders and how innovation competency shaped organizational change outcomes within the context of their organization. Also, it would be helpful to find an in-depth understanding of leadership performance in regards to before and after the innovation competency used in managing change.

The outcome of this phenomenological study could further provide a platform for an empirical test of the innovation competency against the practice of managing change in the context of FBOs. This could be achieved via the examination of the theoretical and practical actualities of innovation competency and management of change in an actual setting of a faith-based organization. Innovation competency has received much attention in recent years at both nonprofit and profits organizational level. Still, few researchers have addressed the perspective of stakeholders regarding innovation competency impact on church leaders within the context of FBOs or Christian churches. Another phenomenological study would be interesting, and such research could focus on members' and donors' perceptions of leader's performance regarding innovation competency and change management. From the study, most of the participants needed collaboration from members for an effective outcome of leaders' innovation competency; therefore, a study can give an insight into their views. Most of the participants perceived a third-party group would be best to assess their performance. Such an investigation could offer useful lessons for other FBOs and NPOs interested in knowing the personal effects of religious leaders with innovation competency.

\section{Conclusions}

Regardless of the positivity of individual faith or getting solace from individual associations with God, church leaders need innovation competency to manage the trend of change in the operational environment, the demands of the people and the learning curve of leadership will have limited growth. Yet, if the occurrences are appropriately recognized, and innovation competency is successfully actualized, Christian church leaders, can manage change for their organizations that mirror their religious values and induce trust in absolute responsibility of church leaders to the growth of the organizations and wellbeing of stakeholders.

The study's results also confirmed the importance of innovation competence in managing change. Church leaders, including leaders from FBOs and NPOs, should consider innovation competency in regards to change management. Additionally, knowledge derived from this study could add to the academic expertise regarding (a) the value of church leadership, (b) support successful change in churches, (c) influence positive change amongst community members and stakeholders, and (d) enhance organizational performance in the NPO sector. Given the importance of innovation competency in achieving successful organizational change results, the study phenomenon could be emulated by FBOs and NPOs leaders for higher performance and growth.

\section{References}

Assouad, A., \& Parboteeah, K. P. (2018). Religion and innovation: A country institutional approach. Journal Of Management, Spirituality \& Religion, 15(1), 20. https://doi.org/10.1080/14766086.2017.1378589

$\mathrm{Au}, \mathrm{C}$. (2017). Ecumenical and Inter-religious engagement of Asian Pentecostals and Charismatics. Ecumenical Review, 69, 527-541. https://doi.org/10.1111/erev.12319

Bielefeld, W., \& Cleveland, W. S. (2013). Defining faith-based organizations and understanding them through research. Nonprofit and Voluntary Sector Quarterly, 42, 442-467. https://doi.org/10.1177/0899764013484090

Boyatzis, R. (1982). The competent manager: A model for effective performance. John Wiley \& Sons. 
Clarke, M., \& Ware, V. (2015). Understanding faith-based organizations: How FBOs are contrasted with NGOs in international development literature. Progress in Development Studies, 15(1), 37-48. https://doi.org./10.1177/1464993414546979

Dukić, G. (2015). Perception and adoption of change management in information institutions: A study from Croatia. Libri: International Journal Of Libraries \& Information Services, 65, 175-190. https://doi.org/10.1515/libri-2014-0162

Einar, B. (2013). Religion and politics in Nicaragua: What difference does a revolution make? Iberoamericana: Nordic Journal Of Latin American And Caribbean Studies, 42, 159-182. https://doi.org/10.16993/ibero.38

Griffith, D. A. (2013). Establishing qualitative geographic sample size in the presence of spatial autocorrelation. Annals of the Association of American Geographers, 103, 1107-1122. https://doi.org/10.1080/00045608.2013.776884

Hmielowski, J. D., Chanjung, K., \& Sungsu, K. (2015). Engaging the congregation: Examining the conditional indirect effects of religious leaders' cues on environmental behaviors. Journal of Communication \& Religion, 38(3), 51-66.

Hong, Y. J. (2012). Best practices in managing faith-based organizations through charitable choice and faithbased initiatives. Journal of Social Service Research, 38, 130-143. https://doi.org/10.1080/01488376.2011.615268

Hopkins, K., Meyer, M., Shera, W., \& Peters, S. C. (2014). Leadership challenges facing nonprofit human service organizations in a post-recession era. Human Service Organizations: Management, Leadership \& Governance. 38(5), 419-422. https://doi.org/10.1080/23303131.2014.977208

Hsiao, W., Lee, C., \& Chang, W. (2017). A constructive factor analysis of innovation competency taking Taiwan students enrolled in design programs as an example. International Conference on Applied System Innovation (ICASI), 2017, 554-557. https://doi.org/10.1109/ICASI.2017.7988481

Janssen, O. (2003). Innovative behaviour and job involvement at the price of conflict and less satisfactory relations with co-workers. Journal of Occupational \& Organizational Psychology, 76, 347-364. https://doi.org/10.1348/096317903769647210

Jaskyte, K. (2015). Board of directors and innovation in nonprofit organizations model: Preliminary evidence from nonprofit organizations in developing countries. Voluntas: International Journal Of Voluntary \& Nonprofit Organizations, 26, 1920-1943. https://doi.org/10.1007/s11266-014-9505-7

Joakim, E. P. \& White, R. S. (2015). Exploring the impact of religious beliefs, leadership, and networks on response and recovery of disaster-affected populations: A case study from Indonesia, Journal of Contemporary Religion, 30, 193-212. https://doi.org/10.1080/13537903.2015.1025538

Jorgenson, J. (2018). Tools of the trade: Creativity, innovation, influence, and advocacy. American Society of Health-System Pharmacists, 75(11), 785-794. https://doi.org/10.2146/ajhp180037

Kane, M. N., \& Jacobs, R. J. (2013). Perceptions of religious leaders' culpability in the United States. Mental Health, Religion \& Culture, 16, 225-253. https://doi.org/10.1080/13674676.2012.656079

Kaunda, C. J. (2016). Checking out the future: A perspective from African theological education. International Review of Mission, 105(1), 113-130. https://doi.org/10.1111/irom.12120

Koch, L. C., Niesz, T., \& McCarthy, H. (2014). Understanding and reporting qualitative research: An analytical review and recommendations for submitting authors. Rehabilitation Counseling Bulletin, 57, 131143. https://doi.org/10.1177/0034355213502549 
Kumar Basu, K. (2015). The leader's role in managing change: Five cases of technology-enabled business transformation. Global Business \& Organizational Excellence, 34(3), 28-42. https://doi.org/10.1002/joe.21602

Langer, J., \& LeRoux, K. (2017). Developmental culture and effectiveness in nonprofit organizations. Public Performance \& Management Review, 4O(3), 457. http//doi10.1080/15309576.2016.1273124

Lee, S. M., \& Trimi, S. (2016). Conceptual paper: Innovation for creating a smart future. Journal of Innovation \& Knowledge, 3(1), 1-8. http://doi.org/10.1016/j.jik.2016.11.001

Lee, S. M., \& Trimi, S. (2018). Innovation for creating a smart future. Jour nal of Innovation \& Knowledge, 3,(1), 1-8. https://doiorg.ezp.waldenulibrary.org/10.1016/j.jik.2016.11.001

Lutz Allen, S., Smith, J. E., \& Da Silva, N. (2013). Leadership style in relation to organizational change and organizational creativity: Perceptions from nonprofit organizational members. Nonprofit Management \& Leadership, 24(1), 23-42. https://doi.org/10.1002/nml.21078

McMurray, A. J., Islam, M. M., Sarros, J. C., \& Pirola-Merlo, A. (2013). Workplace innovation in a nonprofit organization. Nonprofit Management \& Leadership, 23, 367-388. https://doi.org/10.1002/nml.21066

Mogashoa, M., \& Makofane, K. (2017). Challenges facing the ministerial formation in Uniting Presbyterian Church in Southern Africa: A critical reflection. Hervormde Teologiese Studies, 73(3), 1-9. https://doi.org/10.4102/hts.v73i3.3102

Moustakas, C. (1994). Phenomenological research methods. Sage.

Offutt, S., Probasco, L., \& Vaidyanathan, B. (2016). Religion, poverty, and development. Journal for the Scientific Study of Religion, 55, 207-215. https://doi.org/10.1111/jssr.12270

Ogliastri, E., Jäger, U., \& Prado, A. (2016). Strategy and structure in high-performing nonprofits: Insights from Iberoamerican cases. Voluntas: International Journal of Voluntary \& Nonprofit Organizations, 27, 222-248. https://doi.org/10.1007/s11266-015-9560-8

O’Sullivan, D., \& Dooley, L. (2009). Applying innovation. Sage.

Probasco, L. (2016). Prayer, patronage, and personal agency in Nicaraguan accounts of receiving international aid. Journal for the Scientific Study of Religion, 55, 233-249. https://doi.org/10.1111/jssr.12263

Robbins, S. P. (2001). Organizational behavior: Concepts, controversies, and application. Prentice-Hall.

Sangmi, C., \& Jae-Sung, C. (2014). Dynamics of innovation in nonprofit organizations: The pathways from innovativeness to innovation outcome. Human Service Organizations: Management, Leadership \& Governance, 38, 360-373. https://doi.org/10.1080/23303131.2014.898005

Schnable, A. (2016). What religion affords grassroots NGOs: Frames, networks, modes of action. Journal for the Scientific Study of Religion 55, 216-232. https://doi.org/10.1111/jssr.12272

Schultz, T., Vuncannon, J., \& Bump, K. (2016). A pilot study of a scripture-based trauma healing model for adults in Nicaragua. Mental Health, Religion \& Culture, 19, 613-625. https://doi.org/10.1080/13674676.2016.1222606

Singh, S., Corner, P. D., \& Pavlovich, K. (2016). Spirituality and entrepreneurial failure. Journal of Management, Spirituality \& Religion 13(1), 24-49. http://doi.org/10.1177/026624261668560

Spina, N. (2016). The religious authority of the Orthodox Church and tolerance toward homosexuality. Problems of Post-Communism, vol 63(1), 37-49. https://doi.org/10.1080/10758216.2015.1057038 
Szczepaska-Woszczyna, K. (2014). Innovation processes in the social space of the organization. Regional formation \& development studies, 3(14), 220-229. https://doi.org/10.15181/rfds.v14i3.878

Viederytè, R. (2016). Organizational and process innovations in international logistics companies: The relevance and expected benefits. Regional Formation \& Development Studies, 20, 134-146. https://doi.org/10.15181/rfds.v20i3.1350

Vila, L. E., Pérez, P. J., \& Coll-Serrano, V. (2014). Innovation at the workplace: Do professional competencies matter?. Journal of Business Research, 67, 752-757. https://doi.org/10.1016/j.jbusres.2013.11.039

Ware, V.-A., Ware, A., \& Clarke, M. (2016). Domains of faith impact: How "faith" is perceived to shape faithbased international development organizations. Development in Practice, 26, 321-333.

https://doi.org/10.1080/09614524.2016.1149150

The Journal of Social Change, sponsored by Walden University, welcomes manuscripts focusing on interdisciplinary research in social change that improves the human condition and moves people, groups, organizations, cultures, and society toward a more positive future. 